chondral matrix and ossification were active, the mandibular condyle grew normally. In ultrastructural research, the low calcium diet and standard diet with supplementary ipriflavone and $1 \alpha-\mathrm{OH}-\mathrm{D}_{3}$ group showed that the territorial matrixs between chondral lacunae were often found, and the borders of chondral lacunae were distinct. The characteristic of this group was most osteoclasts were inactive and parting from bone matrix, and active osteoblasts lined on the surface of bone formation separated by osteoid

\title{
$\mathrm{P}$ - 3.ラット黒質網様部の微小電気刺激による顎筋および舌筋の活動
}

○天野仁一朗·朴＼cjkstart寅出·村田 貴俊·河岸 重則·吉野 賢一

九歯大·口科

あらかじめ広範な両側性大脳皮質除去を施した浅麻酔ラットの黒質網樣部（SNr）に微小電気刺激（333 Hz， $200 \mu \mathrm{s}, 40$ 発, $40 \mu \mathrm{A})$ による mapping を適用し, 刺激部位の組織学的同定と組み合わせて類顔面領域の筋に活動を 誘発する $\mathrm{SNr}$ 部位を検索した. $\mathrm{SNr}$ 全域を $0.5 \mathrm{~mm}$ 間隔で mapping した結果, Bregma 後方 $5.5 \sim 6.0 \mathrm{~mm}$, 外側 $2.0 \mathrm{~mm}$ の領域の刺激で, 刺激側の咬筋, 顎二腹筋前腹, 上唇挙筋, オトガイ舌筋に顕著な $\mathrm{EMG}$ 活動が出現した. 4

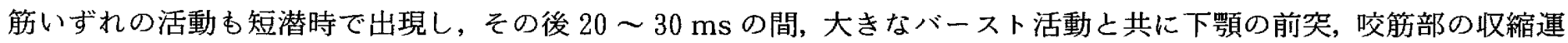
動が目視された．刺激に同期して反対側前肢および同側眼瞼・眼球の運動が観察されることもあった。 $\mathrm{SNr} の 1$ 点刺 激により，神経支配の異なる顎筋，舌筋および顔面筋に協調性活動が誘発されることは興味深い。

Activities in the jaw and tongue muscles by electrical microstimulation of the reticular part of the substantia nigra in rats

Niichiro Amano, Inchul Park, Takatoshi Murata, Shigenori Kawagishi and Kenichi Yoshino (Department of Oral Neuroscience, Kyushu Dental College)

To localize the sites of reticular part of the substantia nigra ( $\mathrm{SNr}$ ) which induce activity in the muscles of orofacial region, mapping by electrical microstimulation ( 40 pulses, $333 \mathrm{~Hz}, 40 \mu \mathrm{A}$ ) was performed in lightly anesthetized rats previously decerebrated. The selected sites were electrolytically marked through an elgiloy microelectrode tip for later histological identification. When the right $\mathrm{SNr}$, 5.5-6.0 $\mathrm{mm}$ posterior to Bregma, $2.0 \mathrm{~mm}$ lateral to the midline, was stimulated, remarkable EMG activities appeared in the ipsilateral masseter, anterior digastricus, genioglossus, and levator labii superioris muscles. Occasional movements of the contralateral forelimb and ipsilateral eye ball were also observed.

$\mathbf{P}-4 . \mathbf{A P}$ 水による止血効果

○古賀裕紀子' ${ }^{1}$ 東 $\quad$ 泉 $^{1} \cdot$ 大住 伴子 $^{1} \cdot$ 黒木賀代子' $\cdot$ 小園 凱夫 ${ }^{2}$ ${ }^{1}$ 九歯大·柬薬理, ${ }^{2}$ 九歯大·歯理工

電解酸性水は，除菌，洗浄などを目的として医療機関などで使われている．新たに開発された，第 2 世代ソフト電 解中性水といわ扎 $\mathrm{AP}$ 水は，経験上創傷部位の止血に効果があると言われている。そこで AP 水をマウス尾部先端 の切断創に適用し，止血時間について検討した，対照薬剤として市販の歯科用局所止血薬を実験に供した，AP 水群 では, 無処置群に比較して止血時間が有意に短縮し， AP 水の効果は $0.1 \%$ エピネフリン液，トロンビン局所用液とほ ぼ同程度であった，以上のことから，AP 水は止血効果があることが判明し，㐘科臨床上局所止血薬としての有用性 が期待される.

\section{Hemostatic effect of AP water}

Yukiko Koga ${ }^{1}$, Sen Higashi ${ }^{1}$, Tomoko Ohsumi ${ }^{1}$, Kayoko Kuroki ${ }^{1}$ and Yoshio Kozono ${ }^{2}$ ( ${ }^{1}$ Department of Dental Pharmacology and ${ }^{2}$ Department of Materials Science, Kyushu Dental College)

Electrolyzed acid water has been used for sterilizing and washing in dental practice. Newly developed AP water, which is called second-generation soft electrolyzed neutral water, experientially appears to be effective in hemostasis. In this study, hemostatic effect was examined. The tail of mice was cut and 
time to stop bleeding was determined. Some commercial dental local hemostatics were used as controls. AP water significantly shortened bleeding time compared to non-treatment. The effect of AP water was at the same level as that of $0.1 \%$ epinephrine solution and liquid with $1000 \mathrm{u} / \mathrm{ml}$ thrombin. These results suggest that AP water is clinically useful as a hemostatic.

\section{$P$ - 5. 口腔腫瘍術後多数菌欠損患者に flange technique を利用した義歯製作}

○堀 祥二1·古橋 会治 ${ }^{2}$.久保 雅晴 ${ }^{3}$

${ }^{1}$ 堀柬科, ${ }^{2}$ 古橋歯科, ${ }^{3}$ 久保歯科

右側上顎歯肉癌切除後, 鼻腔と交通を認めた上顎総義歯症例と, 左㑗下顎エナメル上皮腫切除後, 腸骨移植を行 なった下顎 12 歯欠損症例に対し, flange techniqueを利用して新義歯を製作，装着したところ，良好な結果を得た のでその概要を報告した。

【症例 $1 】(72$ 歳女性)：高松赤十字病院にて右側上靧歯肉癌（T4N1M0, stage IV）の診断の屯と右側全頚部郭清 術および右側上顎部分切除を受けた，術直後より旧義歯修理，新靧義柬装着，調整を行なっていたがより安定した義 歯を希望され来院にた．まず下顎新義歯で咬合平面，人工歯排列位置を決定した後，上顎の精密印象，咬合採得を行 なった，下顎新義歯に合わせて上顎人工歯排列を行ない，口腔内試適後, flange techniqueを利用してロ腔周囲筋に よる唇·煩・口蓋側面の機能的歯肉形成を行なった. 重合, 研磨後さらにdynamic impression を行ない, reliningし た後に装着し，良好な経過を得ている。

【症例 2】(41 歳男性)：18 歳時に左側下顎エナメル上皮腫の診断の屯と東京医科歯科大学病院で左下䫇枝から右 側第 2 小曰歯部までの下顎骨切除および遊離腸骨移植術を受けた，術後に装着した部分床義歯は約 20 年間で数回の relining 等の処置を受けていたが, より安定した新義歯製作を希望して来院された。精密印象，咬合採得を行なった 後 flange technique を用いて下㴿人工歯排列位置を決定し, 排列後口腔周囲筋群の機能運動により唇・㚘頁・舌側面の 歯肉形成を行なった。重合，研磨後装着し良好に経過している。

Denture construction cases using the flange technique for postoperative oral tumor patients with a minimal number of remaining teeth

Shoji Hori ${ }^{1}$, Kaiji Furuhashi ${ }^{2}$ and Masaharu Kubo ${ }^{3}$ ( ${ }^{1}$ Hori Dental Clinic, ${ }^{2}$ Furuhashi Dental Clinic and ${ }^{3}$ Kubo Dental Clinic)

We used the flange technique to construct dentures for two postoperative oral tumor patients and obtained good results.

One of the patients had been diagnosed with a gingival carcinoma of the right maxilla and had had a radical dissection of the right neck and a partial resection of the right maxilla in 1996. The other patient had been diagnosed with a left mandibular ameloblastoma and had had a partial resection of the mandible from the left ramus to the right secondary premolar negion, and a free graft of the iliac bone had been performed in 1977.

After taking ordinary impressions and registering the vertical and horizontal interocclusal relation , we first used the flange technique to record the lower denture \$pace, where the arrangement was made of the lower and upper artificial teeth. We then used the technique to contour (wax) the polished surface of the trial denture, which should be shaped in such a manner as to aid retention by the mechanical directional forces of the surrounding muscles and tissues.

$P-6$. 治療推奨と臨床研究の比較 一歯周治療における咬合調整一

○内藤 徹・天野めぐみ・伊東

本城 祐子·橘川英一郎·菅
憲子·立川 智美·原田真紀子·堀 明日香 義浩·西郡 武史·横田 誠

九歯大·保存 2

蒾周治療における咬合調整について，歯周病関連の教科書での記載と，臨床研究による咬合調整の治療効果の検証 